\title{
THE SCENT OF SAKE: A FAILURE IN THE EMBODIMENT OF JAPANESE WOMAN IDENTITY TO BE AN AUTHENTIC SUBJECT
}

\author{
Zietha Arlamanda Asri ${ }^{1}$, Mira Utami², Sulistya Ningtyas ${ }^{3}$ \\ Alumni S2 Ilmu Sastra Universitas Gadjah Mada \\ ziethahikaru@gmail.com¹, koharami87@gmail.com² ${ }^{2}$ tyas.effendi@gmail.com ${ }^{3}$
}

\begin{abstract}
Identity is seen as something important to humans in society, as it shows the origin of the self. Sometimes, someone cannot accept the identity that is attached to them, which will lead to the process of forming a new identity. This case also happens to the main character of The Scent of Sake, a novel by Joyce Lebra published in 2009. Rie Omura is not allowed to interfere in the sake making business, so that she tries to change that identity. Thus, this study aims to examine the process of identity formation that occurs in the character of a Japanese woman, represented by Rie. To answer the research problem, this study uses a textual analysis as the research methods. The theory used to assist the analysis is a perspective proposed by Žižek regarding the formation of subject's identity to achieve the stage of authentic subject. The results show that in her efforts to unbind herself from the symbolic order, she makes attempts to rule the brewer house. However, her action cannot be categorized as a radical action since it cannot bring her out of the Symbolic. It confirms that Rie is failed to be an authentic subject.
\end{abstract}

Keywords: Japanese Woman, Authentic Subject, Žižek, The Scent of Sake

\begin{abstract}
Abstrak
Identitas dipandang sebagai sesuatu yang penting bagi manusia yang hidup bermasyarakat karena menunjukkan asal-usul. Terkadang, seseorang tidak dapat menerima identitas yang melekat padanya, yang akan memantik tindakannya menuju pembentukan identitas baru. Hal ini juga terjadi pada karakter utama dalam novel "The Scent of Sake" karya Joyce Lebra yang terbit pada tahun 2009. Rie Omura tidak diizinkan ikut campur dalam bisnis pembuatan sake, sehingga dia mencoba mengubah identitas dan pelabelan tersebut. Dengan demikian, penelitian ini bertujuan untuk mengetahui proses pembentukan identitas dalam karakter wanita Jepang, yang direpresentasikan oleh Rie. Untuk menjawab permasalahan penelitian, analisis tekstual digunakan sebagai metode penelitian. Teori yang digunakan untuk membantu analisis adalah perspektif Žižek mengenai pembentukan identitas subjek untuk mencapai tahap subjek autentik. Hasil penelitian menunjukkan bahwa dalam upayanya untuk melepaskan ikatan dari tatanan simbolis, Rie berupaya untuk berperan penting di perusahaan produksi sake milik keluarganya. Namun, tindakannya tidak dapat dikategorikan sebagai tindakan radikal karena tidak dapat membawanya keluar dari Yang Simbolik. Hal ini mengkonfirmasi bahwa Rie gagal menjadi subjek autentik.
\end{abstract}

Kata Kunci: Perempuan Jepang, Subjek Autentik, Žižek, The Scent of Sake 
Poetika: Jurnal Ilmu Sastra

Vol. VII No. 2, Desember 2019
DOI 10.22146/poetika.51610

ISSN 2338-5383 (print); 2503-4642 (online)

\section{Introduction}

Humans are created by having their respective identities. It is difficult to imagine human without identity. According to Gilroy (as cited in Woodward, 1997), humans live in a world where identity matters. It becomes important as it can give an understanding about the self and the fact of being whom or what a person or thing is. To construct the identity, human adopts everything produced by the social and cultural circumstances, in which they can find themselves and draw certain assumptions about their nature, individuality, and the self. In some cases, there are obstacles in the process of forming an identity, which happens when the subject does not accept the identity that has been embedded through culture, customs, social values, etc. In the end, it will give rise to provoke resistance from oneself to change the identity that has been pinned in themselves.

According to Žižek in Myers (2003), the process of forming an identity is not a oneway process. It does not only stop at the moment when the subject is characterized in the symbolic order, but it continues as the subject offers actions whether to accept or reject the given identity. Thus, Žižek through the concept of the authentic subject rejects the assumption that the subject has been written by discourse, that the subject is passive by accepting symbolic confinement, and that the subject always acts according to the social order.

In their journey of forming an identity, there is always a possibility for the subject to take actions as an effort to release their at- tachment to the symbols that shackle them. By cutting this attachment, they are no longer be influenced by anything outside of the self. The process of subjectivity by the big Other makes the subject occupy a position in the Symbolic dimension, but the process does not become the end of the process of forming the subject's identity. The subject has an instinctive and psychological process at the center of the workings of ideology, so there is a point where the subject makes the decision to choose how to respond to actual instructions. Furthermore, the subject continues to move and act to find selffulfillment because in the subject there is always a gap that makes them never complete. Therefore, although shackled by a structure, the subject still has the opportunity to refuse to become a controlled subject.

The case regarding the process of identity formation does not only occur in the real world, but is also widely presented in literary works. That is because there are many literary works that focus on the formation of the identity of a character to build the narration of the story. One of literary works that shows this problem is The Scent of Sake by Joyce Lebra who is a writer and professor at the University of Colorado, United States. As she studies the field of culture and the role of women in Japan, India, and Asia Pacific, this novel about the role of Japanese woman becomes one of her masterpieces.

The Scent of Sake tells the story about a young woman named Rie Omura who is the daughter of famous family sake maker. Rie is not a typical Japanese woman because she has intelligence and highly attentive to family business. She is able to think of various solutions 
related to the problems they face, and has a great sense of discipline and interest in knowing the flows of Omura's sake business. Unfortunately, as a woman, she is forbidden to interfere in male jobs. Then, the family choose a husband for Rie in order to save the future of their business. The husband will be adopted and trained to continue their business. All of the successor of the House of Omura are carefully selected with thorough consideration for the benefit of the Omuras. Only one thing was lacking; Rie's parents never gave their daughter the opportunity to bring out the contents of her deepest heart.

This novel shows the life of Japanese women in the $19^{\text {th }}$ century that is so attached to culture, customs, and social norms. These become standard rules for every respected member of society, which must be obeyed and carried out without ever questioning the worthiness. For Rie as a woman, she can be said to have no voice and rights to determine her personal way of life. It is because women are a companion and supporter of the will and honor of men, especially their respective spouses, and devotion to the family is something that absolutely must be fulfilled. Rie becomes the figure of a woman who is restricted by rules and traditions, but has all the advantages expected of a male figure as a prospective heir to her family business.

Lebra's narration in the The Scent of Sake novel that presenting Rie as a leading woman character is in the grip of a symbolic order in the form of customs and social structures that label women as girls in a box. However, there are times when Rie gives different ac- tions as a form of character implications in subjectivity. This is based on the inconvenience of her identity and position as a woman who is deemed unfit to make sake. That causes the character not to simply accept the identity given. Therefore, the objective of this study is to examine the process of identity formation that occurs in the character of a Japanese Woman, represented by Rie Omura.

In this study, the authors used a textual analysis as the research methods. Thus, the data are in the form of text from The Scent of Sake novel by Joyce Lebra as the material object. The data collected are then analyzed by applying the psychoanalysis methods from Slavoj Žižek as the formal object. At this point, the process is done by preparing and organizing the data, reading the data, analyzing the data by creating categories, and finally interpreting the data. Furthermore, based on Žižek's problem formulation and theoretical concepts regarding the formation of the subject's identity, an analysis was conducted to find out the identity formation in the character of Rie in the novel The Scent of Sake.

Based on the observation has been found that there is no research that explores the subject's identity in Joyce Lebra's The Scent of Sake by applying Slavoj Žižek's theory. The mapping results that have been filtered according to their relevance to this study showed that there are two studies that have a similar material object and three studies that have a similar formal object with this study.

Regarding the novel as material object, a study by Mianani \& Wardani (2018) examined the concept of masculinity in The Scent of Sake. 
Another study which also used the same literary work is a study by Rullyanti \& Sari (2015) which analyzed Rie as the main character of the novel through the perspective of radical libertarian feminism. Both focused on the masculinity and femininity which dominate the plot of the story. Thus, it can be seen that these two studies did not elaborate on the process of forming the subject's identity as a whole.

Regarding the theory as the formal object, the first is a study by Shkandrij (2010) which explored the concept of the object of desire in some best poems of Oleksandr Irvanets. The second is a study by Adkins (2017) which scrutinized his critiques on neoliberalism and moralism in Salman Rushdie's The Satanic Verses. The last is a study by Wang \& Keong (2014) which inspected Žižek's jouissance. Those studies can be worthy references in executing the literary work in this study because they give details of Žižek's ideas clearly.

This study applies a theoretical concept proposed by Slavoj Žižek concerning the process of forming the subject's identity. Žižek, a Slovenian-born philosopher, sees that the diversity is apparent. He criticizes how contemporary thinkers forget about the uniqueness of the subject that sinks instead of being free. Žižek suggests that we should return to the Cartesian-style subjects. However, Žižek then tries to construct a new perspective on this type of subjects (Johnston, 2008; Sharpe \& Boucher, 2010; Žižek, 1998).

By using Hegelian negativity, Marxist dialectics, and Lacan's psychoanalysis, Žižek seems to succeed in explaining radical subjects (Parker, 2004). He uses dialectic, oxymoronic Hegelian in analyzing the subject matter. For him, psychoanalysis is an appropriate method of human reading. Without abandoning the Hegelian method, he dialyzes the Imaginary Order, Symbolic Order, and Real Order inherited from Lacan's psychoanalysis. The results of dialectics in humans apparently affect the way humans think about ideology. Žižek states that "for Lacan, psychoanalysis at its most fundamental is not a theory and technique of treating psychic disturbances, but a theory and practice that confronts individuals with the most radical dimension of human existence". Thus, Žižek adopted the notion of the subject from Lacan's thoughts.

In Lacan's philosophy, subject always experiences lack (manque, in his original term) ever since the subject was born. This lack is like a hole in the self, which continues to occupy the unconscious mind of the subject (Faruk, 2012). This lack is the core reason that causes the desire to arise (Lacan, 2006). The subject, who constantly encounters the lack, will always make an effort to fulfill the lack in themselves by driving their desire. However, the subject is indeed mediated by the Other's desire, in which this desire will only find its meaning in the Other's desire (Lacan, 2006).

Žižek borrowed the triad concepts of the Imaginary, the Symbolic, and the Real from Lacan to break down the manifestation of identity in the subject. In the imaginary stage (mirror stage), the subject cannot distinguish the self from the Other. The subject is a free individual from the symbolic order surrounding them 
(symbolized with $S$ ). When the subject sees their shadow on the mirror, they can differentiate themselves from the objects that are not a part of them. However, the figure they recognize from the reflection on the mirror is nothing but an image. The subject misrecognizes themselves, which is why this stage is called the imaginary stage (Lacan, 2006). As emphasized by Žižek, the process of subjectivization is where the subject is given an identity and also where that identity is altered or changed by the Self (Myers, 2003). In this case, the recognition is in the realm of identity which is given.

The end of the imaginary stage is marked by the opening door of the symbolic stage in which the subject makes negotiation with language. There is clearly a play on language in the legitimacy of power. The authority gives an identity so that the subject feels comfortable without knowing that the identity is given in return for trusting the authority, directing the subject's mind to support that power. This signifying chain limits the subject so that they are imprisoned by the language itself. In other words, they are forever bound as they will never reach absolute freedom to understand the world as it really is. This process leads the subject from a free individual to be a split subject (symbolized as \$) (Lacan, 2006). By using the language, the subject tries to patch the hole in themselves to reach the Real.

The Real is an indefinable concept beyond the symbolic order. This symbolic order is a form of a social structure called the big Other, which is a representation of macro institu- tions such as the state, religion, and government (Robet, 2010). As long as the desire of the subject is established to answer Che vuoi? (what the Other wants from me?), they will never reach the Real. What is desired by the subject will only become objet petit $a$, a void which becomes object-cause of desire (Žižek, 2008; Manik, 2016). In Kantian ideas, this object refers to the transcendental object, the $\mathrm{X}$ factor, which is completely separated from the symbolic order (Žižek, 2008).

A way carried out by the subject to manipulate the Real is called ideological fantasy. Žižek moves beyond Marxian thoughts which formulates ideology as false consciousness (the subject does not know what they are actually doing, but they do it anyway). Meanwhile, rooting from an opinion from Sloterdijk, Žižek defines ideology as cynical consciousness (the subject knows what they really do, but they do it anyway) (Žižek, 2008). In other words, ideological fantasy refers to a means used by the subject so that their knowledge about the Real is manipulated.

In the journey to reach the Real, the subject must do a radical action to bring themselves out from the Symbolic. When the subject can liberate themselves from the Gaze of the Other, it is possible that they undertake a radical action (Miller, 1988). An action can be categorized radical if it is done spontaneously without any plan and does not has any particular intention or purpose (Setiawan, 2015). In this momentum, the subject can be said to have reached the Real, which affirms their state to be an authentic subject. 


\section{The Failure of A Subject to be Authentic in}

\section{The Scent of Sake}

The Scent of Sake is a depiction of child position; girl and boy, in their life as the successor of Japanese sake brewer family. In Japan, the business of sake brewing is embraced as hereditary. The skill of sake brewing runs through generations, from the father to son. Only the son of the family who allowed to take and handle the business, from the brewing process to selling. "Woman will ruin the sake and make the taste sour" is the myth that hold back woman from being engaged with the industry.

This novel depicts the life of Rie Omura as the only daughter of Omura family who run their sake business named White Tiger for generations. The death of Toichi, Rie's younger brother, who also should be the successor of White Tiger had shaken Omura family, so did Rie who felt the guilty for did not taking care of Toichi. Thus, she made up her mind to keep their family business on its track even bigger. Rie leapt the boundaries which restrain every Japanese woman who was born in sake brewer families. She tried to prove that myths and taboos as well as prohibitions embraced by Japanese woman which restrain her acts were non-existent matters that can be broken down. Rie then helped the business from under the table, gave hints as well as secret proposal and ideas that made Omura's business expanded well, even bigger than when being managed by her father. But then, did Rie succeed to be an authentic subject with her desire which is an anomaly in sake business in Japan?
As Žižek adopted from Lacan's theory regarding subject, there is symbolic order which become the boundaries for the subjects to act and behave. The symbolic order, which limits the subject from the Real, functions as a control in the subject's social life. The existence of a symbolic order is only limited to subjective presuppositions imagined by the subject. In other words, that dimension will come into existence only when the subject considers it to exist. Even if the subject tries to understand the whole symbolic reality, they will never find anything. The integrity of the symbolic reality which consists of democratic ideology, power, and the process of economic (re)production will actually disappear when the subject tries to formulate it (Žižek, 2006).

The symbolic order could shape a subject as its role in an individual life. Subjects can reach the Real or not based on how the symbolic order worked on them. Žižek stated that in the journey to reach the Real, the subject must do a radical action to bring themselves out from the Symbolic. When the subject can liberate themselves from the Gaze of the Other, it is possible that they undertake a radical action (Miller, 1988).

That question is a challenge to find out whether Rie as the main character experiences the stages of identity formation refer to Žižek's point of view regarding the subject. Identity formation to become the Real needs several psychological stages. The subject can be ended becoming cynical or false in the consciousness, as Žižek is pointed at how the psychological stages can be successful, or fail. 
The Process of Identity Formation in Rie as A Daughter of Sake Brewer Family

This part will discuss the life of Rie Omura who stands out as the daughter of brewer family. From Japanese culture point of view, women have particular duty that should be fulfilled. They have to manage domestic works, and produce heirs to carry family's line on. Meanwhile, as the women who was born in sake brewer family, comparing to other women, they embrace more important value that is going to help their family as well.

As a woman born in a sake brewer family, theoretically, Rie should not have to worry about family business, in this case the White Tiger, a sake brand under Omura family which had been inherited over generations up to his father. By the myths and taboos that restrained every woman either in general or they as the descendant of sake brewer, Rie actually could avoided the responsibility to continue family business. However, Rie's characteristic showed her distinction that made her decided to not choosing the image which showed "I am a Japanese woman" with all obligations, responsibilities, oppressions, prohibitions, or restraints.

One picture of a Japanese woman is how they looked, as stated below:

Rie's hair was piled into three sections over which was laid the wide white silk band to hide the bride's "devils' horns," symbolizing that a wife was never to display jealousy, whatever her husband chose to do. (Lebra, 2009: 14).

It is clearly explained how a woman should behave as a wife who have to obey and subject to her husband no matter the condition they faced in the future, reflected in how they being adorned in wedding ceremony.

Rie's anomalous character is showed clearly since her childhood. For her, prohibitions did not act as taboo that need to be obeyed, as pictured by Lebra in the very beginning to bold the distinction in Rie's character. Rie had grown her fond towards sake since her childhood. She roamed around the brewery although her father prohibited her to do so for the sake of sake, as shown in the quoted paragraph below:

Let a woman enter the brewery and the sake will sour," the old ones always said. Her mother had warned her of this since childhood. But Rie relished the yeasty smell of brewing sake that hung in the air. She had always played near the door and the barrels as a child. As a little girl, she had waited, terrified, for the news that the sake had soured. (Lebra, 2009: 12).

The process of mirror stage takes place at this moment. The familiarity upon sake shown in Rie's love towards the smell of yeast and fermenting sake, particular smells that entice her. It marked the initial phase of Rie in defining herself as a child who grown up in sake brewer family. Suryajaya (2014) quoted Žižek who adopted Lacan's three stages of subject's identity formation. It begins with mirror stage as the process of identity formation of a subject in imaginary stage, acted as the initial process of subject's identity formation. It is started when an individual reach the age six months old, when individuals does not have the capability to distinct themselves with everything around.

People's sense of self will obtain through the image reflected by the mirror-with possible connotation meaning-that shape their self as an individual. This matter also stated by Lacan as "the sphere of identification", which is the most basic psychological process (Olivier, 
Poetika: Jurnal Ilmu Sastra

Vol. VII No. 2, Desember 2019

2004). In Rie's case, she found her visual as a "girl", thus when she stubbornly spent her time playing around the brewing room though she had been warned to not doing so, at the end it still raised anxiety and fear on her that arose a question, will the sake become sour later?

Imaginary stage is followed by symbolic stage, which is the phase when individual cannot avoid the Symbolic. Language as the Symbolic forces individuals to give up their imaginary identity. Žižek quoted Lacan who described that any kind of universe cannot be liberated from language, thus the horizon of meaning on those universes will always attached to the Symbolic (Sulistyaningtyas, 2019). This matter is related with Althusser's formula regarding ideology apparatus which also emerge in Lacan's. Ideological State Apparatus (ISA) is non-repressive ideology that control individuals act and behavior. However, the non-repressive traits have stronger control upon individuals compared to SA (State Apparatus) which actually works in repressive way (Manik, 2015). Although the State and its apparatus such as bureaucracy, administration, military, police, and prison have the power to oppress, the facts state that social orders including religion, culture and tradition, politic, education, family, union, and communication have such bigger power to restrain and control. In the other words, ISA is related to the Symbolic.

As she finished scrubbing the last of the barrels all she got was blue-cold hands and a scolding from her father. "Yes, Father. But I do not want to leave this job to others. It's too important. And I'm not so near the door." She glanced up briefly, and looked down again. "Get back to the kitchen!" Kinzaemon
DOI 10.22146/poetika.51610

ISSN 2338-5383 (print); 2503-4642 (online)

bellowed. Rie was careful not to let her anger and disappointment show. (Lebra, 2009: 3).

She thought suddenly of the way her father banished her to the kitchen, wanted to keep her away from the business side of the brewery, especially transactions involving cash, something to which women of Kansai merchant houses had no access. (Lebra, 2009: 9).

The facts occurred are what Rie had faced as a daughter "of sake brewer family". ISA in form of tradition controls the way of a woman to act and behave. As a woman in Japan conventional era, her duty was to do domestic works. Her place was on the kitchen. Meanwhile as a daughter of sake brewer family, she could not get her hand on their business in the name of tradition. Yet, born and grown up in merchant's family also grew her fondness of business, particularly in sake making and trading, as stated in the following.

Even as a child she had taken an interest in her father's business, and now she felt a greater urgency. (Lebra, 2009: 20).

Jihei worked at his eyebrows again and shifted uneasily. "I wonder if the daughters of other houses are as active as you." "Well, I'm an only child and have always loved brewing, even when I was little." She smiled, tentatively. (Lebra, 2009: 23).

One important thing that make a huge difference for daughters of brewer families is their value to expand the business, as stated below:

Everyone knew that sake brewing was a man's world, and Kinzaemon could have brought a geisha's son into the house. But with the Kansai chonin, the merchants, they often preferred to adopt a husband for a daughter, an adult clerk who had proven his mettle and would be an asset to the family business. It was common practice among brewers, a good business strategy. (Lebra, 2009: 3).

The quotation shows the Symbolic which rules the way daughters of brewer families should be living. A daughter is an asset to be married off into another brewer family so that 
Poetika: Jurnal Ilmu Sastra

Vol. VII No. 2, Desember 2019

the family practically get a son to continue and develop their business. The practice particularly embraced by Kansai's merchants. So did Rie who should marry Jihei, a son from Okamoto family which run sake business as well. The Symbolic forced Rie to subject upon the ruling tradition, strengthened by quotation below:

It was natural, then, for the marriage of two major brewing houses to be viewed as an event of great importance. (Lebra, 2009: 12).

Lacan conveys that the Symbolic always raise negativity in individual, something called as lack. With the lack they felt inside, individuals then try to patch the holes that lead them to the Real. When the subject tries to think dialectically about the phenomena they encounter, in the end there will be upheaval between the Symbolic and the Real. As a solution, the subject unconsciously fantasizes certain ideologies, so that their knowledge of the Real is manipulated. Meanwhile, the Real is something that goes far beyond the Symbolic, individuals then manipulate it through ideological fantasy (Suryajaya, 2014).

Rie is aware of her lack. Her sense of guilt for being unable to watch her little brother which ended in Toichi's death, then her position as a daughter who couldn't step in into family's business while she had many ideas and breakthroughs regarding the way to expand their business and developed White Tiger. Her intelligence trapped only because she was a woman, thus Rie tried to move and handle their business secretly under her father's nose.
DOI 10.22146/poetika.51610

ISSN 2338-5383 (print); 2503-4642 (online)

She would have to catch Kin sometime alone and talk to both him and Jihei about increasing market share. There was nothing to prevent her from going to the office in the evening after her father had left. (Lebra, 2009: 22).

That was Rie's effort in patched her lack. Her needs and desire to take over the business was the picture of an individual to fulfill the emptiness of lack within. In that way, family business became her objet petit $a$ which attracted her desire, as stated by Lacan, acted as the objective materialization of lack inside the individual (Suryajaya, 2014).

The pressure of the Symbolic towards Rie also came from the obligation to "kill" herself for the sake of her marriage. It meant that the woman who married with unknown man: a stranger; someone who didn't get her attention and love; she needed to kill the self for that kind of marriage. In other words, it meant that she had to put her desire aside and killed her feelings, wishes and hopes, as well as the rights to embrace happiness.

Hana leaned forward slightly. "And you must try to be a good wife, Rie. Be compliant. Your feelings must not intrude." Hana put down her sewing and looked at Rie's face. "Women often find it necessary to 'kill the self.' Otherwise life becomes too difficult. (Lebra, 2009: 7).

Based on the quotation above, it could be assumed that the pressure came from the symbolic of Japanese convention regarding woman who will get married. The Symbolic ruled every woman to subject towards the husband, even if they had to sacrifice their feelings and their longing for happiness.

The point where she had to kill herself rather shaped Rie's character, raised her consciousness of the Real. When she was being 
asked by her mother to kill herself so that they can had successor by taking a husband from brewer family for Rie, she decided to pick her own way to resolve herself to reject the Symbolic, as shown in the following

Arranged marriage was the way. She would not kill the self. She would find a way to survive. (Lebra, 2009: 8).

Rie became more stubborn to do the business in order to relieve her stress and pain for having a lot of difficulties. Not only she needed to kill herself for her unpleasant marriage, she also lost her fetus, got cheated, had to push herself to serve her husband for the sake of an heir of her own blood, and took Jihei's children from geishas he met into their house.

The later is the turning point in Rie's life, when the family found out that Jihei had a child with geisha. The tradition was taking the child into their house as adopted child. When a family didn't have grandchildren and the son or son-in-law had a child with geisha, they had to adopted the child and made it the successor.

With a sharp intake of breath, Rie looked down at her clenched fists and avoided her mother's gaze for several minutes. Shame burned her cheeks as she thought of her husband with the geisha and a child together, so soon after her own miscarriage! Anger quickly suffused shame. (Lebra, 2009: 44).

The anger that came from the truth about his husband had a child with geisha raise the awareness of revenge in her. Rie manifested her anger and revenge by pursuing his lover Saburo whom had the same feeling with her. At that point, Rie was in the state of performed cynical consciousness. She really wanted her own child which nearly impossible to achieve after miscarriage their first child and with Jihei who became more distant for having affairs with geisha. In order to preserve Omura's bloodline and got her happiness, she secretly met Saburo, did intercourse with that man, and got pregnant with his child, something that she really wanted. Rie fully understood that her act was dangerous because she could end dead if that affair got caught, as stated below:

She was in love with Saburo. Deeply in love. And he had given her enough subtle clues that he felt the same. She just hoped that they didn't get caught. She knew the penalty for a woman would be severe, probably even death. (Lebra, 2009: 89).

At the end, her cynical consciousness formed in her one-night stand date with Saburo, as her revenge and her way to seek happines resulted on Rie's pregnancy, and a daughter named Fumi.

Rie heard the words she wanted to hear. "It's a girl, so the house will prosper," the midwife pronounced. [...] It was a blessing that the baby was a girl, since there would be little possibility that she would resemble Saburo so closely as to arouse suspicion. "Fumi," Rie whispered, and put her arms around her baby. (Lebra, 2009: 107).

By all substances of the Symbolic, Rie realized the lack of herself as the result of Other's desire. Her marriage was forced; she couldn't grow fond to Jihei as that man was not a warm and sensitive person; above all, Rie fell in love to another man named Saburo from Kato brewer family. However, Rie's cynical consciousness was her ideological fantasy to manipulate the Real. The Real in reference to Rie's desire will be discussed in following section. 
Poetika: Jurnal Ilmu Sastra

Vol. VII No. 2, Desember 2019
DOI 10.22146/poetika.51610

ISSN 2338-5383 (print); 2503-4642 (online)

\section{Rie's Failure to be an Authentic Subject}

Subject's submission towards the symbolic order, which called as subjectivity in poststructuralism, is a one-way process. It means that the subject accepts all form of the big Other interpellations without resistance, to step out from the circle of that symbolic dimension. In The Scent of Sake-just like in any other reality-there is no subject that capable to be fully liberated from the big Other. Then, a question arises; how the subject responded to that trap?

In her case, Rie resisted the symbolic order by taking the important part in the House of Omura. Since beginning, Rie always shared her ideas through Kin, the family's chief clerk as well as her father's right hand. She put her influence in business decisions and moves. Even when her father was dead and replaced by Jihei as his successor, Rie confirmed herself to take the control of their business after her father entrusted their family's seal to her. Family seal is the symbol of power because it will be used to mark approval in every decision making.

Before Kin left he told her what her father wanted to tell her before he died: how proud he was of her, and that he wanted to give her the family seal. Kin handed Rie the seal Kinzaemon had entrusted to him the night before he died, asking that he give it to Rie with his special blessing. (Lebra, 2009: 154).

With the seal in her hands, Rie became braver to make risky decisions, such as made loan system for temple that drawn negative impression and talks among their society for its contradiction with moral values of society. Rie took a radical movement in the momentum when she did intercourse with Saburo, her true lover. Her act was the culmination point of her concern and anxiety regarding the House of Omura. She sent a letter to Saburo secretly, which temporarily became the sign that Rie had doing a radical act for doing something which violated the symbolic order in Japan, because not only she sent a letter to a man, but also was someone's wife. Her act went beyond the Symbolic.

However, Rie's effort to reach the absolute authentic ended in a big failure, no other that the symbolic order itself, because she is still trapped in it. Gaze of the big Other made her recreated the life she had in her descendants by proceeded with the tradition. Although the decisions she took brought particular concerns and worry for herself, Rie still trapped in the Symbolic with her carried on the decisions for her children and grandchildren the same way her parents did for her, as stated in the following quote:

To Rie's disappointment, he carefully avoided her eyes. She knew in the long run that this was the right thing and he would thank her later, but she felt an unease recalling his adamant opposition to the thought of marrying Tama, whom he found so unattractive. Rie disliked the idea of imposing an unhappy marriage, perhaps similar to her own. Yet she felt Tama would add strength to the house. That had to take precedence. (Lebra, 2009: 205-206).

Yoshi had been surly ever since the wedding. Try as she might to appease him, he had not settled in well with Tama. Rie feared that the two might end up like herself and Jihei. She hoped not, but for now she needed to focus on finding husbands for Fumi and Kazu. Then she would deal with Tama and Yoshi. (Lebra, 2009: 213).

These quotations show the decisions made by Rie to push Yoshi as Head of the House into a marriage he did not want to do. She also did the same thing to her daughters regarding mar- 
riage, as in quotation below:

As Rie looked at the tense expressions on both faces she recalled her mother's words on the eve of her marriage to Jihei. She hesitated, then repeated the words to her daughters: "Sometimes, a woman must 'kill the self' in order to survive. What this means is that we women can never behave selfishly [...]" Rie stopped speaking and smiled inwardly at each anxious expression. Fumi and Kazu had not taken their eyes from Rie's face as she talked. She thought she detected a pout on Teru's face as she listened with her sisters. (Lebra, 2009: 218).

The quotation above shows the biggest failure she did, for repeating her mother's words that she deeply detests, for what she became a woman who survived the marriage. The logic of Rie should be the cause of her process to be authentic subject, because she refused to kill herself, instead tried to survive. However, although she might succeed to survive and gained her desire to step into the business, she still trapped in symbolic order regarding how she treated her children. It shows Rie's cynical consciousness. Not only pushed her children in an arranged marriage, she also applied the rules that restrain woman to step into brewing room to her daughters. She even felt fear as the reek of guilt toward her daughter-in-law who had the same experience with the marriage, just like her cold relationship with Jihei, as well as the guilt to push Yoshi to marry a girl he did not like only because Tama came from a brewer family like them, as shown in quotation below:

Yoshi had been surly ever since the wedding. Try as she might to appease him, he had not settled in well with Tama. Rie feared that the two might end up like herself and Jihei. (Lebra, 2009: 213).

All those matters, however, did not stop
Rie to fulfill her desire for the House of Omura, became the moment where Rie did her ideological fantasy for doing things that showed her cynical consciousness. Even with her big step to got pregnant with Saburo, the act was planned, and Rie was fully aware with the consequence. Rie could not be the authentic subject because her acts could not be considered as radical, which made her fail in her effort to be authentic, because at the end she still proceeded with the Symbolic.

\section{Conclusion}

In The Scent of Sake novel, the symbolic order is represented by the exteriority of Japanese circumstances in the $19^{\text {th }}$ century. At that time, woman is not allowed to get involved in the brewing business, which is regarded as male domain. However, Rie makes an attempt to be free from the restrain by playing an important role in the company, and fulfill her desire to be with her lover who is a married man. At first glance, the actions seems to be radical. However, since this action cannot bring Rie to be free from the Symbolic, it cannot be categorized as radical actions. Conversely, she repeats the pattern of what has happened to her life into the life of her children. Though she experiences guilt by doing so, she does it anyway. It indicates her cynical consciousness to manipulate the Real. In the end, she fails to reach the stage to be an authentic subject as she is still shackled by the Symbolic.

\section{References}

Adkins, A. 2017. Neoliberalism, Moralism, and Critique in Salman Rushdie's The Satanic Verses, Critique: Studies in Contemporary 
Fiction, 58 (1), 12-27.

Faruk. 2012. Metode Penelitian Sastra: Sebuah Penjelajahan Awal. Yogyakarta. Pustaka Pelajar.

Johnston, A. 2008. Žižek's Ontology, A Transcendental Materialist Theory of Subjectivity. Evanston: Northwestern Univ Press.

Lacan, J. 2006. Écrits: The First Complete Edition in English. Translated by Bruce Fink from Écrits. New York: W.W. Norton \& Company.

Lebra, Joyce. 2009. The Scent of Sake. New York: William Morrow Paperbacks.

Manik, R.A. 2016. Hasrat Nano Riantiarno dalam Cemin Cinta: Kajian Psikoanalisis Lacanian. Jurnal Poetika, IV (6), 74-84.

Mianani, S.S.\& Wardani, E.D. 2018. The Questioning of the Concept of Masculinity in Joyce Lebra's The Scent of Sake. Journal of Language and Literature, 18 (1), 41-49.

Myers, T. 2003. Slavoj Žižek. New York: Routledge.

Parker, I. 2004. Slavoj Žižek, A Critical Introduction. London: Pluto Press.

Robet, R. 2010. Manusia Politik: Subyek Radikal dan Politik Emansipasi di Era Kapitalisme Global menurut Slavoj Žižek. Tangerang: Marjin Kiri.

Rullyanti, M. \& Sari, S.P. 2015. An Analysis of Libertarian Radical Feminism on Rie's
Character in Joyce Lebra The Scent of Sake 2009. Literary Criticism, 2 (1), 27-34.

Setiawan, R. 2018. Žižek, Subjek, dan Sastra. Yogyakarta: Jalan Baru.

Sharpe, M. \& Boucher, G. 2010. Žižek and Politics, A Critical Introduction. Edinburgh: Edinburgh University Press.

Shkandrij, M. 2010. The Shifting Object of Desire: The Poetry of Oleksandr Irvanets. $\mathrm{Ca}$ nadian-American Slavic Studies, 44, 67-81.

Sulistyaningtyas. 2019. Paralaks dalam Novel My Name is Red Karya Orhan Pamuk. Unpublished thesis. Yogyakarta: UGM.

Wang, A.L.W.\& Keong, S.C. 2014. Just Jouissance: Discerning and Subverting a Politics of Inherent Transgression in Malaysian Socio-Political Discourse. Asian Journal of Political Science, 22 (2), 147-163.

Woodward, K. 1997. Concepts of Identity and Difference. In K., Woodward (Ed.).Identity and difference. London: Sage/The Open University.

Žižek, S. 1998. The Cartesian Subject versus the Cartesian Theatre. In S., Žižek (Ed.). Cogito and the Unconscious. Durham: Duke University Press.

Žižek, S. 2001. On Belief. New York: Routledge.

Žižek, S. 2008. The Sublime Object of Ideology. London: Verso. 